\title{
Neutrophil migration into the bovine uterine lumen following intrauterine inoculation with killed Haemophilus somnus
}

\author{
B. M. Butt ${ }^{1}$, P. L. Senger ${ }^{2 *}$ and P. R. Widders ${ }^{1} \dagger$ \\ ${ }^{1}$ Department of Veterinary Microbiology and Pathology, Washington State University, Pullman, \\ WA 99164-7040, USA; and ${ }^{2}$ Department of Animal Sciences, Washington State University, \\ Pullman, WA 99164-6332, USA
}

\begin{abstract}
Summary. Polymorphonuclear neutrophils (PMN) in bovine uterine flushings following intrauterine deposition of killed bacteria were measured and the effect of immune status on the influx of PMN into the uterine lumen during oestrus was determined. Holstein heifers were immunized with a $270-\mathrm{kDa}$ outer-membrane protein (omp-270) from Haemophilus somnus. During oestrus, immunized heifers $(n=21)$ received an intrauterine inoculum of either a heat-killed suspension of a homologous strain of $H$. somnus containing omp-270 $(n=7)$, a heterologous strain of $H$. somnus lacking omp-270 $(n=7)$, or phosphate-buffered saline $(n=7)$. Five additional heifers were inseminated with extended bovine semen. Uterine contents were collected in saline lavage immediately before inoculation $\left(\mathrm{t}_{0}\right)$ and at $6,24,48,72,96$, and $120 \mathrm{~h}$ after inoculation. The semen-inoculated heifers were lavaged only at $t_{120}$. All groups experienced PMN infiltration which peaked $6 \mathrm{~h}$ after inoculation and tended to decline thereafter. Differences were not observed between treatment groups, indicating that neither bacterial inoculation nor immune status was as important in eliciting PMN effusion as the flushing procedure itself.
\end{abstract}

Keywords: uterus; immunology; neutrophils; cow

\section{Introduction}

Bovine intrauterine infections contribute significantly to reproductive failure in cattle (Sagartz \& Hardenbrook, 1971; Hartigan et al., 1972; Studer \& Morrow, 1978; Paisley et al., 1986). Intrauterine infections in cattle have been associated with abortion (Roberts, 1986; Widders et al., 1986), early embryonic death (Kaneene et al., 1986a, b) and infertility (Griffin et al., 1974; Studer \& Morrow, 1978). Understanding uterine defence mechanisms is essential for developing effective treatment and preventative strategies and for optimizing reproductive performance.

It is accepted that polymorphonuclear neutrophils (PMNs) are the predominant phagocytic cell type in the bovine uterus during the follicular phase of the cycle. These cells can function as nonspecific phagocytes or in the presence of opsonizing antibody can contribute to specific immunity. However, PMNs can reduce fertility through their effects on sperm function and viability (Targowski et al., 1985), embryo survival (Smith et al., 1971; Bo et al., 1975; Anderson \& Alexander, 1979) and implantation (Waites \& Bell, 1982).

Uterine PMN effusion is known to occur during the follicular phase of the normal bovine oestrous cycle (Skjerven, 1956; Hartigan et al., 1972). At times other than oestrus, the presence of 
PMNs in the uterine lumen is considered pathological (Skjerven, 1956; Studer \& Morrow, 1978). Ovarian hormones are thought to play a major role in mobilization and activation of PMN in the uterine lumen (Black et al., 1960; Broome et al., 1960; Hawk et al., 1960a, b, c), but the kinetics of PMN migration has not been defined in normally cycling cows, or in heifers given intrauterine inoculations of semen or bacteria.

Immune status has been reported to be important in PMN mobilization to the guinea-pig uterus. Targowski (1984) has demonstrated that there was an increase in PMN mobilization into the uterus in systemically immunized guinea-pigs following a homologous intrauterine challenge when compared with controls.

The aim of this investigation was to define the kinetics of PMN mobilization into the bovine uterus at oestrus in response to inoculation of heat-killed $H$. somnus and to determine the effect of immune status on PMN recruitment to the uterus.

\section{Materials and Methods}

Preparation of a 270-kDa outer-membrane protein for immunization. Selection of the protein (omp-270) in this study was based on its antigenicity, ease of preparation and the availability of isolates of $H$. somnus that expressed or lacked omp-270. Suspensions of $H$. somnus 2336 were grown in brain and heart infusion broth (Difco Laboratories, Detroit, MI, USA) supplemented with $0.1 \%$ Tris and $1 \mu \mathrm{g}$ thiamine monophosphate $/ \mathrm{ml}$ to log phase, and centrifuged at $9148 \mathrm{~g}$ for $15 \mathrm{~min}$. Pellets were discarded and the supernatant was filtered through $0.45-\mu \mathrm{m}$ filters. This filtrate was ultracentrifuged at $245000 \mathrm{~g}$ for $2 \mathrm{~h}$ to pellet membrane vesicles. This fraction contained omp-270 as well as other surface proteins (Yarnall et al., 1988). Supernatants were discarded and membrane vesicles resuspended in the residual volume. Pooled samples were fractionated by gel filtration (Sephadex CL4B: Pharmacia LKB Biotechnology, Inc. Piscataway, NJ, USA). Fractions were analysed for the presence of omp- 270 by sodium dodecyl sulphate polyacrylamide gel electrophoresis. Fractions containing only omp-270 were pooled and dialysed exhaustively against distilled water. The pooled, dialysed fractions were lyophilized.

Bacteria. Heat-killed suspensions of $H$. somnus strains 2336 and IP were prepared for inoculation. The 2336 strain was isolated from the lungs of a cow which had died of pneumonia. This strain contains an omp-270 used to immunize all heifers in this experiment (Widders et al., 1989). The IP strain, which does not contain omp-270, was isolated from the prepuce of a clinically normal bull (Widders et al., 1989). Bacteria were grown to log phase and centrifuged as described above. Pellets were resuspended in phosphate-buffered saline (PBS) to $5 \times 10^{7}$ colony-forming units $/ \mathrm{ml}$, determined spectrophotometrically. Bacteria were killed by heating at $60^{\circ} \mathrm{C}$ for $10 \mathrm{~min}$ and the sterility of the suspensions was confirmed by culture.

Animals and immunization. Thirty Holstein heifers, $\sim 12$ months old, were obtained from a commercial dairy in central Washington State, WA, USA. No animal contained demonstrable serum antibody titres to the omp-270 antigens prior to the experiment. All heifers were immunized (i.m.) with $10 \mu \mathrm{g}$ omp-270 in Freund's incomplete adjuvant on Days 1 and 35 of the experiment.

Detection of oestrus. All animals were injected (i.m.) with $25 \mathrm{mg}$ prostaglandin-2 $\alpha$ (The Upjohn Company, Kalamazoo, MI, USA) on Days 50 and 60 . Beginning $48 \mathrm{~h}$ after the second prostaglandin injection (Day 62) all animals were observed every $6 \mathrm{~h}$ for signs of behavioural oestrus. Only those which stood to be mounted were included in the experiment. A total of 26 heifers qualified.

Treatment groups. Four treatment groups were used to examine uterine effusion. Animals within each group received intrauterine inoculations of either $H$. somnus 2336 (containing omp-270), H. somnus IP (lacking omp-270), PBS, or extended bovine semen.

Sampling technique and treatment administration. Eight hours after the first observation of standing heat, uterine lavage was performed using the method of Anderson et al. (1985). Epidural anaesthesia was performed to reduce rectal contractions and facilitate passage of the catheter through the cervix. The perineum was thoroughly cleaned with chlorhexidine (Virosan, Boehringer Ingelheim, St Joseph, MO, USA). A 14-gauge Rausch catheter was passed into the right uterine horn, the cuff inflated and $30 \mathrm{ml}$ of sterile $0.01 \mathrm{M}$ PBS, pH 7.4, was infused into the right horn; $5-25 \mathrm{ml}$ infusate was recovered by aspiration using a $30-\mathrm{ml}$ syringe. After flushing and while the catheter was still in place, $0.5 \mathrm{ml}$ of one of the following treatments was infused into the right uterine horn: $5 \times 10^{7}$ heat-killed $\mathrm{H}$. somnus of either the homologous or heterologous strains; or PBS. Another $1.0 \mathrm{ml}$ PBS was infused immediately after this treatment, to ensure that all bacteria entered the uterus. Additional flushings using $30 \mathrm{ml}$ PBS were obtained at 6,24 , $48,72,96$ and $120 \mathrm{~h}$ after the initial inoculation.

PMN quantitation. The total number of nucleated cells was counted in uterine flushings by haemocytometry. Additional aliquots were cytocentrifuged (Cytospin, Shandon Southern, Inc., Astmoor, Runcorn, Cheshire, UK) 
and stained with Diff-Quik (Baxter Healthcare Corp., McGaw Park, IL, USA) and differential cell counts performed by a single observer on 100 cells. A $1 \mathrm{ml}$ aliquot from each sample was evaluated for the presence of haemoglobin (Cyanmethaemoglobin technique using a Colter haemoglobinometer, Colter Electronics, Inc., Hialeah, FL, USA) to identify animals undergoing iatrogenic uterine trauma or metoestrus bleeding. Those samples positive for haemoglobin and subsequent samples from the same animals were removed from the study.

Because the volume of fluid recovered from the uterus varied $(5-25 \mathrm{ml} /$ flush) the concentration of PMN was standardized to total uterine protein (TP) to normalize for these volume differences. The concentration of TP will also differ between cows and with the magnitude of PMN infiltration. However, with lavage fluids this calculation permits the most accurate analysis of the kinetics of cellular infiltration currently available.

All flushings were centrifuged at $1300 \mathrm{~g}$ for $10 \mathrm{~min}$. Total protein content was measured colorimetrically with a commercial staining kit (Bio-rad protein assay: Bio-rad Laboratories, Richmond, CA, USA) using the following modification. A $5 \mu \mathrm{l}$ sample was mixed with $300 \mu \mathrm{l}$ dye in 96 -well plates. After $5 \mathrm{~min}$ at room temperature optical density was measured at $950 \mathrm{~nm}$.

Statistical analysis. The rank sum test was used to detect differences between treatment groups at any sampling time and to detect differences within any one treatment group with respect to time.

\section{Results}

Exfoliate epithelial cells, macrophages, lymphocytes, eosinophils and PMNs were observed in uterine flushings. The predominant cell type in $t_{0}$ flushings was the exfoliate epithelial cell $(97 \%)$, which as a percentage of total cells declined in subsequent flushings. Macrophages were absent from $t_{0}$ flushings and reached their peak at $t_{48}$, comprising $\sim 10 \%$ of the luminal cells. Lymphocytes and eosinophils were seen sporadically and at low concentrations.

Flushings obtained immediately before the challenge $\left(\mathrm{t}_{0}\right)$ contained $2 \cdot 7 \%$ PMNs $(n=21)$ (Fig. 1a). An increase in percentage PMN $(P<0.005)$ occurred between $t_{0}$ and $t_{6}$ for all treatment groups. This represented the peak PMN effusion in the saline and homologous groups, PMN reaching 44,51 and $55 \%$ in the saline, homologous $H$. somnus and heterologous $H$. somnus groups, respectively. Treatment influenced neither the degree nor the timing of PMN effusion $(P>0 \cdot 25)$. Mean \% PMN declined with succeeding sampling times in all groups, with the exception of a slight increase at $\mathrm{t}_{24}$ in the heterologous group. At $\mathrm{t}_{120}, \% \mathrm{PMN}$ did not differ from $\mathrm{t}_{0}$ levels $(P>0.05)$. Uterine flushings from heifers inseminated with extended bovine semen at $t_{0}$ and lavaged only at $\mathrm{t}_{120}$ contained $3 \cdot 0 \%$ PMN.

The PMN concentration (cells $/ \mathrm{ml}$ ) in uterine flushings was standardized to TP concentration $(\mu \mathrm{g} / \mathrm{ml})$. At $\mathrm{t}_{0}, 11 \mathrm{PMN} / \mu \mathrm{g}$ TP was observed $(n=19)$ (Fig. $\left.1 \mathrm{~b}\right)$. A significant increase in PMN/TP occurred in all groups between $\mathrm{t}_{0}$ and $\mathrm{t}_{6}(P<0.05)$, with values of 884,1075 and $732 \mathrm{cells} / \mu \mathrm{g}$ in the homologous, heterologous and PBS groups, respectively. As with \%PMN, PMN/TP remained above $t_{0}$ values in all groups from $t_{6}$ to $t_{96}(P<0 \cdot 05)$. Uterine flushings obtained at $t_{120}$ did not differ significantly from $\mathrm{t}_{0}$ samples $(P>0 \cdot 3)$. Uterine flushing obtained 5 days after artificial insemination contained mean PMN/TP values similar to those observed at $t_{0}(9.0 \pm 8.4$ vs. $18 \cdot 0 \pm 23 \cdot 1)$

\section{Discussion}

These results describe the temporal pattern of PMN infiltration into the bovine uterine lumen. At the first sampling point $\left(\mathrm{t}_{0}\right), 8 \mathrm{~h}$ after observation of standing heat, PMN concentrations were low relative to the total number of cells and to TP concentration in uterine flushings. Peak PMN effusion was observed $6 \mathrm{~h}$ after the initial uterine lavage. No detectable differences were noted in the magnitude or the time of onset of PMN infiltration between cows receiving saline lavage alone and those receiving an inoculum of killed bacteria.

Our results suggest that uterine lavage had little immediate effect because PMN effusion was negligible at $t_{0}$. However, uterine lavage did influence subsequent flushings. All treatment groups experienced marked PMN effusion $6 \mathrm{~h}$ after the first lavage was obtained. Williamson et al. 

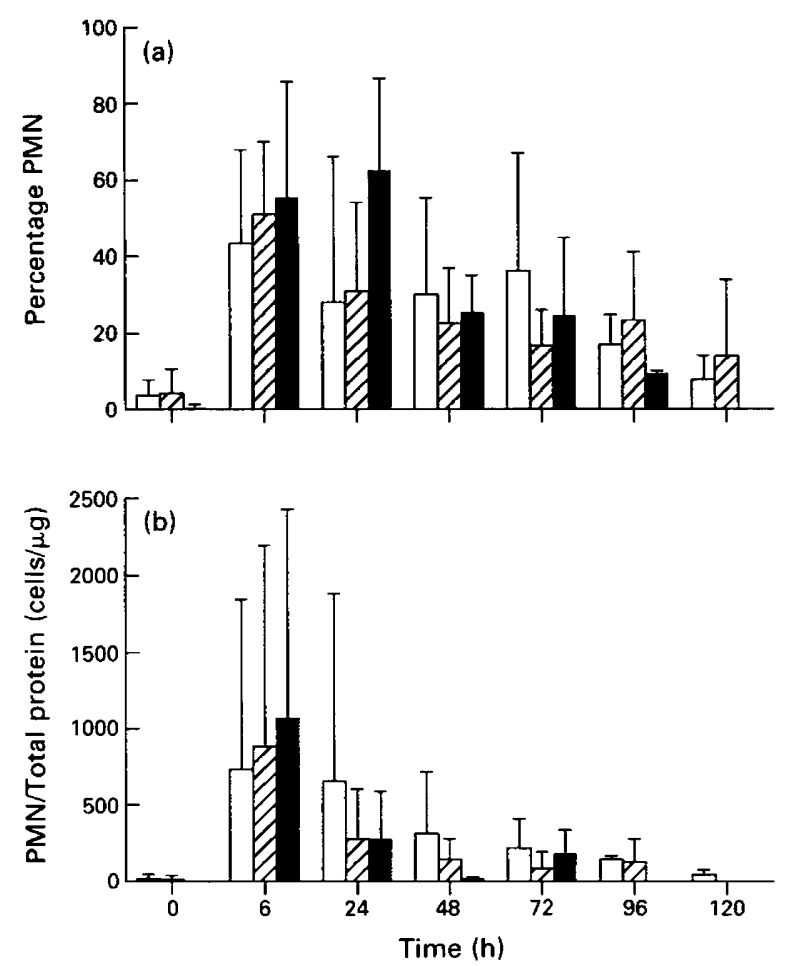

Fig. 1. Results of flushings obtained from bovine uteri following immunization with Haemophilus somnus, homologous strain $\square$, heterologous strain $\square$ or phosphate-buffered saline (control) $\square$. (a) Percentage of cells obtained from uterine flushings which were polymorphonuclear neutrophils (PMN); (b) concentration of $\mathrm{PMN}$ as a proportion of the total uterine protein (TP) shown in the $120 \mathrm{~h}$ following immunization.

(1987) reported a significant uterine PMN effusion in mares $6 \mathrm{~h}$ after cervical or uterine stimulation. Therefore, delayed effusion in cows may be due, in part, to physical stimulation of the endometrium with fluid installation.

During oestrus there was minimal PMN content in the uterus. Time zero samples contained a very low proportion of PMN compared with other cell types present or with TP. While PMNs have been shown to phagocytize sperm in vitro (Mattner, 1969), our results indicate that sperm are initially exposed to a uterine environment with few PMNs. Five days after artificial insemination PMN levels were also low, indicating that embryos are not normally exposed to a leukocytic environment upon entering the uterus.

Unlike Targowski's (1984) findings in guinea-pigs, we were unable to demonstrate that immune status influenced PMN recruitment into the bovine uterus. Homologous inoculation with heatkilled $H$. somnus did not increase PMN mobilization into the uterus when compared with controls. No significant differences were detected between the homologous and heterologous groups, or between the homologous challenge group and the PBS control group. Immunization, if it had an effect, was less important than lavage itself.

We thank D. Jones, C. Quirk, A. Thompson, M. Yarnall and G. Gallagher for help with oestrus detection, sample preparation, and artificial insemination; and T. Besser and C. Lichtensteiger for valuable assistance in statistical analysis. We would also like to thank The Cow Palace for supplying the heifers. 


\section{References}

Anderson, D.J. \& Alexander, N.J. (1979) Induction of uterine leukocytosis and its effect on pregnancy in rats. Biol. Reprod. 21, 1143-1152.

Anderson, K.L., Hemeida, N.A., Frank, A., Whitmore, H.L. \& Gustafsson, B.K. (1985) Collection and phagocytic evaluation of uterine neutrophilic leukocytes. Theriogenology 24, 305-317.

Black, W.G., Simon, J., McNutt, S.H. \& Casida, L.E. (1960) Investigations on the physiological basis for the differential response of estrous and pseudopregnant rabbit uteri to induced infection. Am.J. vet. Res. 14, 318-323.

Bo, W.J., Krueger, W.A. \& Sain, L.E. (1975) Effect of direct injection of neutrophils from uterine horns of rats containing intrauterine devices into recipient pregnant uteri. Fert. Steril. 27, 1318-1321.

Broome, A.W., Winter, A.J., McNutt, S.H. \& Casida, L.E. (1960) Variations in uterine response to experimental infection due to the hormonal state of the ovaries. II. The mobilization of leukocytes and their importance in uterine bactericidal activity. Am. J. vet. Res. 21, 675-681.

Griffin, J.F.T., Hartigan, P.J. \& Nunn, W.R. (1974) Nonspecific uterine infection and bovine fertility. II. Infection patterns and endometritis before and after service. Theriogenology 1, 107-115.

Hartigan, P.J., Murphy, J.A., Nunn, W.R. \& Griffin, J.F.T. (1972) An investigation into the causes of reproductive failure in dairy cows. Ir. vet. J. 26, 225-228.

Hawk, H.W., Turner, G.D. \& Sykes, J.F. (1960a) Noncellular bactericidal factors in inflammatory exudates from the uterine and pleural cavities of estrous and pseudopregnant rabbits. Am. J. vet. Res. 21, 657-663.

Hawk, H.W., Turner, G.D. \& Sykes, J.F. (1960b) The effect of ovarian hormones in the uterine defense mechanism during the early stages of induced infection. Am. J. vet. Res. 21, 644-648.

Hawk, H.W., Turner, G.D. \& Sykes, J.F. (1960c) The bactericidal properties of uteri and uterine exudates of rabbits with reduced leukocytic activity. Am. J. vet. Res. 21, 649-656.

Kaneene, J.B., Coe, P.H., Gibson, C.D., Yamini, B., Marinez, R.O. \& Morrow, D.A. (1986a) The role of Haemophilus somnus in early embryonic death. I. The effect of the organism on embryos by day 8 postbreeding. Theriogenology 26, 189-198.

Kaneene, J.B., Gibson, C.D., Coe, P.H. \& Morrow, D.A. (1986b) The role of Haemophilus somnus in bovine early embryonic death. II. Persistence of the organism in the uterus following intrauterine exposure. Theriogenology 26, 795-801.

Mattner, P.E. (1969) Phagocytosis of spermatozoa by leucocytes in bovine cervical mucus in vitro. $J$. Reprod. Fert. 20, 133-134.
Paisley, L.G., Michelsen, W.D. \& Anderson, P.B.S. (1986) Mechanisms and therapy for retained fetal membranes and uterine infections of cows: A review. Theriogenology 25, 353-381.

Roberts, S.J. (1986) In Veterinary Obstetrics and Genital Diseases (Theriogenology), pp. 126-138. Steven J. Roberts, Ithaca, NY, USA.

Sagartz, J.W. \& Hardenbrook, H.J. (1971) A clinical bacteriological and histologic survey of infertile cows. J. Am. vet. med. Ass. 158, 619-622.

Skjerven, O. (1956) Endometrial biopsy studies in reproductively normal cattle - clinical, histochemical and histological observations during the estrous cycle. Acta. Endocr. 22 (suppl), 1-101.

Smith, D.M., El Sahwi, S., Wilson, N. \& Moyer, D.L. (1971) Effect of polymorphonuclear leukocytes on the development of mouse embryos cultured from the two cell stage to blastocysts. Biol. Reprod. 4, 74-83.

Studer, E. \& Morrow, D.A. (1978) Postpartum evaluation of bovine reproductive potential: comparison of findings from genital tract examination per rectum, uterine culture, and endometrial biopsy. J. Am. vet. med. Ass. 172, 489-494.

Targowski, S.P. (1984) Immune-mediated migration of neutrophils into the uterine lumen of guinea pigs. Am. J. Reprod. Imm. 6, 190-194.

Targowski, S.P., Hartmen, G. \& Warner, D.P. (1985) Activation of phagocytic cells in the uterus. Am. J. Reprod. Imm. 7, 133, abstr. 19.

Waites, G.T. \& Bell, S.C. (1982) Glycogen-induced intrauterine leukocytosis and its effect on mouse blastocyst implantation in vivo and in vitro. $J$. Reprod. Fert. 66, 563-569.

Widders, P.R., Dorrance, L.A., Yarnall, M. \& Corbeil, L.B. (1989) Immunoglobulin-binding activity among pathogenic and carrier isolates of Haemophilus somnus. Infect. Immunity 57(2), 639-642.

Widders, P.R., Paisley, L.G., Gogolewski, R.P., Evermann, J.F., Smith, J.W. \& Corbeil, L.B. (1986) Experimental abortion and the systemic immune response to 'Haemophilus somnus' in cattle. Infect. Immunity 54, 555-560.

Williamson, P., Munyua, S., Martin, R. \& Penhale, W.J. (1987) Dynamics of the acute uterine response to infection, endotoxin infusion and physical manipulation of the reproductive tract in the mare. $J$. Reprod. Fert. Suppl. 35, 317-325.

Yarnall, M., Gogolewski, R.P., \& Corbeil, L.B. (1988) Characterization of two Haemophilus somnus Fc receptors. J. gen. Microbiol. 134, 1993-1999.

Received 20 August 1990 